\title{
DEVELOPMENT OF MULTI-PURPOSE PORTABLE AIR OZONATOR BASED ON SURFACE DBD
}

\author{
V.S. Taran!, I.E. Garkusha ${ }^{1,4}$, P.M. Vorontsov ${ }^{2}$, I.N. Boldyriev ${ }^{3}$, Yu.P. Gnidenko ${ }^{4}$, \\ A.V. Klosovskij ${ }^{1}$, A.V. Taran', A.S. Lozina ${ }^{1}$ \\ ${ }^{1}$ Institute of Plasma Physics, National Science Center "Kharkov Institute of Physics and \\ Technology", Kharkiv, Ukraine; \\ ${ }^{2}$ Sytenko Institute of Spine and Joint Pathology, National Academy of \\ Medical Sciences of Ukraine, Kharkiv, Ukraine; \\ ${ }^{3}$ NPP “HARTRON-PLANT" LtD, Kharkiv, Ukraine; \\ ${ }^{4}$ V.N. Karazin Kharkiv National University, Kharkiv, Ukraine \\ E-mail:avtaran@ukr.net
}

In this paper we describe a compact, economical, easy to use air ozonator developed at the Institute of Plasma Physics of the NSC KIPT and manufactured in collaboration with Public Joint Stock Company «HARTRON-PLANT» LtD. Ozonator of OzD 10/0.1-type uses a surface dielectric barrier discharge to generate ozone from flowing air oxygen, has a flexible system of settings, and is an autonomous and mobile sanitary device for the disinfection of closed spaces up to $500 \mathrm{~m}^{3}$. The output ozone concentration reaches $0.1 \mathrm{~g} / \mathrm{m}^{3}$ with productivity of $10 \mathrm{~g} / \mathrm{h}$. A microprocessor controller has been developed to control the operation of the ozonator. The results of bacteria inactivation in two various premises for surgical operations are presented.

PACS: $52.70 . \mathrm{Ds} ; 52.70 \mathrm{Kz}$

\section{INTRODUCTION}

For more than 100 years, ozone, considered a natural killer of the viruses and bacteria, has been widely used for disinfection, sterilization, deodorization, detoxification, storage and bleaching due to its strong oxidative action, and therefore ozone should be used as a weapon in the global fight againstSARS-CoV-2 [1]. Ozone gas has a number of potential advantages over other decontaminating gases and liquid chemical applications. Thus ozone is a natural compound, is easily generated in situ from oxygen or air, and breaks down to oxygen with a half-life of about $20 \mathrm{~min}$ ( \pm 10 min depending on the environment) [2]. It has the following three main advantages.

1. Full coverage. Ozone generated by ozone generators or electrostatic air purifiers can reach any corner of the environment, which can overcome the problem that ultraviolet sterilization can only go straight up and down, leaving places unsterilized. So, in terms of its bactericidal effect on microorganisms, ozone surpasses the ultraviolet radiation of quartz lamps.

2. Effective detergent. Oxidation of bacteria and viruses is how ozone works, without toxic residues. On the contrary, the chemical disinfectant we use now is not only harmful to the human body, but will also cause a secondary population of toxic residues. During the current epidemic, the overuse of disinfectants has become a serious problem. Ozone can successfully replace chlorine-containing antiseptics.

3. Convenience. Ozone can be made with simple equipment. Equipment, large or small, can be used for a single room, a large public space, or for public transportation modes such as buses, high-speed railways, ships, and aircraft.
The efficiency of ozone for inactivation of bacteria and viruses is not tied only to the ozone concentration, temperature, flow rate, but it is also depends on bacteria types. The environment to be treated must be free of people and animals due to the relative toxicity of ozone via inhalation.

Ozone technologies based on dielectric barrier discharges (DBD) at atmospheric pressure have been extensively studied at IPP NSC KIPT and are applied for sterilization and disinfection purposes in medicine and industry and for other domestic purposes. Lowtemperature sterilizers based on reactors with DBD and surface discharge (SD) operated in water solution were developed [3-6].

The air ozonator is designed to generate gaseous ozone used for disinfection and deodorization of air, disinfectant treatment of technological premises, warehouses, cold rooms, technological equipment (including containers and pipes), disinfection in clinics and hospitals, where there are a large number of infected patients, and also in surgical premises for continuously maintaining sterility of air during surgery. It can be also used for destruction of surface mold and dephenolization of premises, and also to eliminate unwanted odors and smoke. Ozone treatment of food products (including fruits and vegetables) allows increasing their shelf life without losing consumer properties.

\section{DBD REACTORS AND CONSTRUCTIONAL FEATURES OF OzD 10/0.1-TYPE OZONATOR}

There are a large number of options for performing a barrier discharge, however, the principle of a classical barrier discharge is preserved everywhere. The ISSN 1562-6016. BAHT. 2021. №1(131) 
discharge occurs between metal electrodes and a dielectric installed between them in the gas gap. When a voltage is applied, micro-discharges appear on the electrode surface, the number of which increases with increasing voltage. Each micro-discharge collects current from a certain surface of the dielectric. The lifetime of an individual micro-discharge is $\tau=10^{-6} \mathrm{~s}$. The barrier discharge is characterized by a high electron energy of $4 \ldots 5 \mathrm{eV}$ and a low gas temperature $\mathrm{T}=500 \mathrm{~K}$.

DBD can be grouped into three types according to the arrangement of the electrodes and the dielectric: Volume Discharge (VD), Surface Discharge (SD) and Coplanar Discharge (CD). VD arrangements are the most studied and used, however, SD arrangements can provide greater efficiencies, but they have not been widely studied. DBDs exhibit electrode configurations in which at least one of the electrodes is covered by a dielectric to limit the charge transfer, and therefore, the current flowing through and the power deposited in the plasma discharge. Two types of DBDs can be defined: if the plasma is generated between two electrodes, the discharge is commonly referred to as volume dielectric barrier discharge (VDBD). On the other hand, if the electrode gap is completely filled by a dielectric and the plasma is generated along the surface of the dielectric, the discharge is usually termed as surface dielectric barrier discharge (SDBD) or surface microdischarge [7].

Ozonators based on other types of discharges are inferior in performance to designs based on barrier discharge. Ozone production efficiency can be increased by simultaneously generating two types of discharge. The most convenient and energy-efficient way to produce ozone is a barrier-surface discharge.

Structurally, the OzD 10/0.1-type ozonator is made in the form of a portable small-sized device and includes the following main units and elements: housing, tubular reactor, a high-voltage transformer, a fan, a microprocessor control unit and a converter board. The side panel contains an ozonator switch on/off button and microprocessor controls for regimes set and timing (Fig.1). The right side with the grill is the ozone outlet, and the left serves as an air intake. The ozonator is built on the principle of the formation of ozone from oxygen in the air when interacting with a sliding barrier high-voltage electric discharge.

Table 1

\begin{tabular}{|l|c|}
\hline \multicolumn{1}{|c|}{ Type model } & OzD10/0.1 \\
\hline Ozone productivity, g/h & $4,6,8,10$ \\
\hline $\begin{array}{l}\text { Output ozone } \\
\text { concentration, } \mathrm{g} / \mathrm{m}^{3}\end{array}$ & 0.1 \\
\hline Air flow rate, $\mathrm{m}^{3} / \mathrm{h}$ & 120 \\
\hline Power, W & 220 \\
\hline Power consumption, W & $(300 \pm 10) \%$ \\
\hline
\end{tabular}

Fig. 2 shows a conical reactor for generation of the SDBD. The reactor consists of 24 quartz tubes $120 \mathrm{~mm}$ long with $8 \mathrm{~mm}$ outer diameter. An electrode in the form of a metal spiral is located on the surface of the dielectric tubes. The second electrode is a stainless foil placed inside the tube.
According to the mass balance, the required productivity of the ozonator in a given volume of the room is calculated by the formula:

$$
G(m g / \text { hour })=\frac{K(5-10) \times C\left(m g / m^{3}\right) \times V\left(m^{3}\right)}{T(\text { hour })}
$$

At $T=1$ or more, the ozonator generates an almost unchanged concentration. The $\mathrm{K}$ coefficient reflects the half-life of ozone. In practice, $\mathrm{K}$ ranges from 5 to 10 for different rooms.

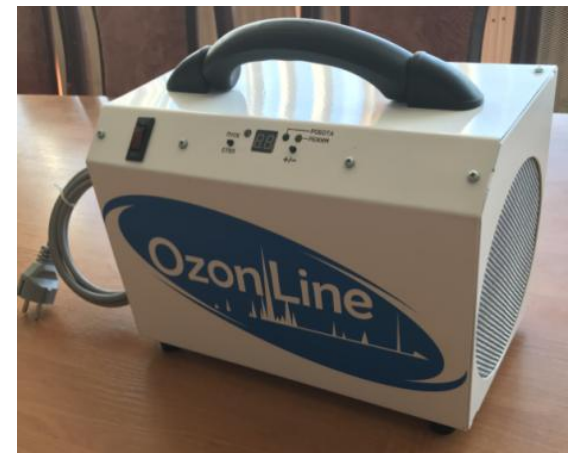

Fig. 1. General view of OzD10/0.1-type ozonator

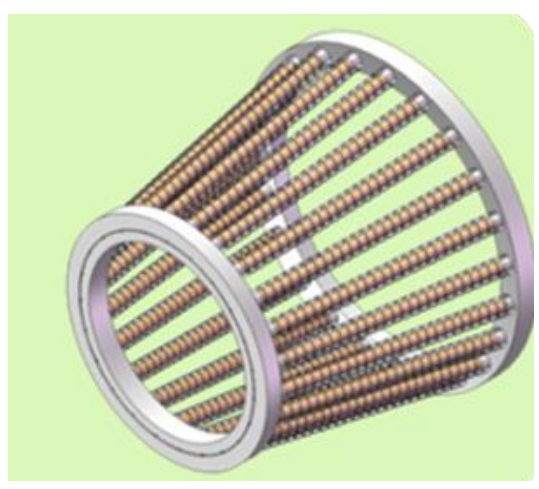

Fig. 2. Conical type reactor of the SDBD

Hence, for a known volume of a room with a volume of $\mathrm{V}$ and available maximum productivity $\mathrm{G}$, for a time $T=1$ hour, the maximum concentration in the room is determined:

$$
C\left(m g / m^{3}\right)=\frac{G(m g / h o u r)}{K(5-10) \times V\left(m^{3}\right)}=\frac{10000}{5 \times V\left(m^{3}\right)}=\frac{2000}{V\left(m^{3}\right)}
$$

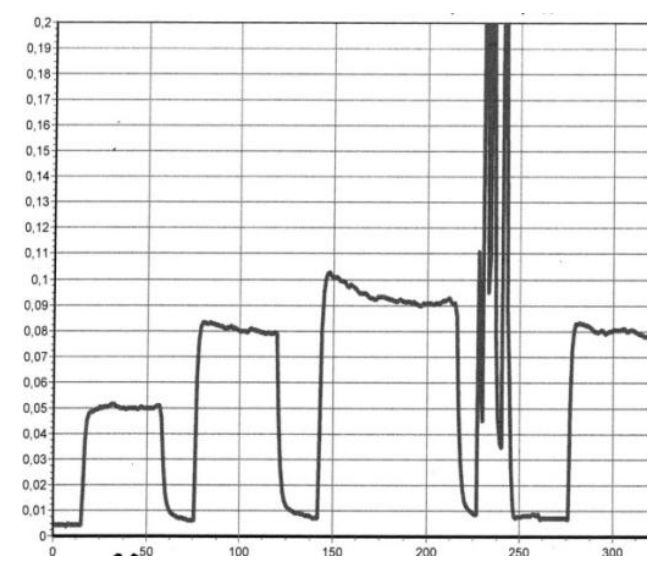

Fig. 3. Dependence of ozone concentration on supplied power $S D B D$ 


\section{BACTERIA INACTIVATION}

The results of bacteria inactivation in two various premises for surgical operations are presented in Table 2. The ozonator was operated at $10 \mathrm{~g} / \mathrm{h}$ mode for $1 \mathrm{~h}$. As a result of ozone treatment the data was obtained considering various types of microorganisms including E. Coli, Alcaligenes Fecalis, Kl. Pneumonia, Bac. Subtillis, Sarcinae etc.

Table 2

\begin{tabular}{|c|c|c|}
\hline \multirow{17}{*}{$\begin{array}{c}\text { Purulent } \\
\text { surgery } \\
\text { room } 1\end{array}$} & $\begin{array}{c}\text { Before } \\
\text { ozonation }\end{array}$ & $\begin{array}{c}\text { After } \\
\text { ozonation }\end{array}$ \\
\hline & \multicolumn{2}{|c|}{ flashes } \\
\hline & E. Coli -7 & not found \\
\hline & KI. Pneumonia - 2 & - \\
\hline & Citrobacter freundi - 1 & - \\
\hline & Ps. Vulgaris - 1 & - \\
\hline & Alcaligenes fecalis - 2 & - \\
\hline & St. epidermitits- 17 & 7 \\
\hline & Bac. Subtillis - 1 & - \\
\hline & Sarcinae - 2 & 2 \\
\hline & E. Faecalis - 2 & - \\
\hline & E. Faecium - 20 & - \\
\hline & \multicolumn{2}{|l|}{ In Air } \\
\hline & 550 in $1 \mathrm{~m}^{3}$ & 140 in $1 \mathrm{~m}^{3}$ \\
\hline & St. Epidermitits - 370 & 140 in $1 \mathrm{~m}^{3}$ \\
\hline & Sarcinae - 120 & not found \\
\hline & mold & - \\
\hline \multirow{11}{*}{$\begin{array}{l}\text { Purulent } \\
\text { surgery } \\
\text { room } 2\end{array}$} & \multicolumn{2}{|c|}{ flashes } \\
\hline & E. Coli -2 & not found \\
\hline & KI.Pneumonia- 1 & - \\
\hline & Sarcinae -2 & 2 \\
\hline & Alcaligenes Fecalis - 2 & not found \\
\hline & Bac. Subtillis - 1 & - \\
\hline & St. Epidermitits - 12 & 8 \\
\hline & \multicolumn{2}{|c|}{ In Air } \\
\hline & 450 in $1 \mathrm{~m}^{3}$ & 180 in $1 \mathrm{~m}^{3}$ \\
\hline & St. Spidermitits - 200 & 130 \\
\hline & Sarcinae -250 & 50 \\
\hline
\end{tabular}

\section{CONCLUSIONS}

The OzD10/0.1-type ozonator has been developed on the basis of a SDBD. A microprocessor controller has been developed to control the operation. According to the results of ozone treatment, E. coli, Alcaligenes Fecalis, Kl. Pneumonia, B. Subtillis bacteria disappeared after ozone treatment. The amount of microorganisms in the air decreased by $60 \%$, including St. Epidermitits by $35 \%$, and Sarcinae by 80 , i.e. by 5 times.

\section{REFERENCES}

1. Ozone Therapy ISCO3. ISCO3/EPI/00/04. Potential use of ozone in SARS-CoV-2 / COVID-19 // Official Expert Opinion of the International Scientific Committee of Ozone Therapy (ISCO3). ISCO3/EPI/00/04 (March 14, 2020). Approved by ISCO 3 on $13 / 03 / 2020$.

2. James B. Hudson, Manju Sharma, and Selvarani Vimalanathan. Development of a Practical Method for Using Ozone Gas as a Virus Decontaminating Agent // Ozone: Science and Engineering. 2020, № 3, p. 216-223.

3. V.S Taran, V.V. Krasnyj, A.V. Klosovski. Plasma sterilizer with ultrasonic cavitation // Problems of Atomic Science and Technology. Series «Plasma Physics». 2007, № 1, p. 188-190. 4. A.S. Lozina, V.S. Taran, V.V. Krasnyj, O.G. Chechelnitskij, A.V. Schebetun. Investigation of ozone decay half-life in dependence of temperature and humidity as well as $\mathrm{H}_{2} \mathrm{~S}$ and $\mathrm{NH}_{3}$ oxidation mechanism // Problems of Atomic Science and Technology. Series «Plasma Physics». 2017, № 1, p. 244-246.

5. A.S. Lozina, V.S. Taran, V.V. Krasnyj, A.V. Taran. Lowtemperature ozone sterilizer based on reactor with electrolytic cell // Problems of Atomic Science and Technology. Series «Plasma Physics». 2019, № 1, p. 149-151.

6. V. Taran, I. Garkusha, A. Taran, et al. Portable ozone sterilization device with mechanical and ultrasonic cleaning units for dentistry // Review of Scientific Instruments. 2020, v. 9. 7. V.I. Gibalov, G.J. Pietsch. Dvelopment of dielectric barrier discharges in gas gaps and on surfaces // Journal of Physics. D.: Applied Physics. 2000, v. 33, p. 2618-2636.

Article received 03.01.2021

\section{РАЗРАБОТКА МНОГОФУНКЦИОНАЛЬНОГО ПОРТАТИВНОГО ВОЗДУШНОГО ОЗОНАТОРА НА ОСНОВЕ ПОВЕРХНОСТНОГО ДИЭЛЕКТРИЧЕСКОГО БАРЬЕРНОГО РАЗРЯДА В.С. Таран, И.Е. Гаркуша, П.М. Воронцов, И.Н. Болдырев, Ю.П. Гниденко, А.В. Клосовский, \\ А.В. Таран, А.С. Лозина}

Представлен компактный, экономичный, простой в использовании воздушный озонатор, разработанный в Институте физики плазмы ННЦ ХФТИ, который выпускается совместно с НПП «ХАРТРОН-ПЛАНТ» ЛТД. Озонатор OzD10/0.1 генерирует поверхностный диэлектрический барьерный разряд для образования озона из проходящего воздуха, имеет гибкую систему настроек и является автономным и мобильным санитарным устройством для дезинфекции закрытых помещений до $500 \mathrm{~m}^{3}$. Разработан микропроцессорный контроллер для управления работой озонатора. Представлены результаты инактивации бактерий в двух различных помещениях для хирургических операций.

\section{РОЗРОБКА БАГАТОФУНКЦІОНАЛЬНОГО ПОРТАТИВНОГО ПОВІТРЯНОГО ОЗОНАТОРА НА ОСНОВІ ПОВЕРХНЕВОГО ДІЕЛЕКТРИЧНОГО БАР'ЄРНОГО РОЗРЯДА В.С. Таран, І.С. Гаркуша, П.М. Воронцов, І.М. Болдирєв, Ю.П. Гниденко, А.В. Клосовський,} А.В. Таран, А.С. Лозіна

Представлено компактний, економічний, простий у використанні повітряний озонатор, розроблений в Інституті фізики плазми ННЦ ХФТІ, який випускається спільно з ПАТ «ХАРТРОН-ПЛАНТ»ТОВ. Озонатор OzD10/0.1 використовує діелектричний бар'єрний розряд для генерації озону з повітря, що проходить, має гнучку систему налаштувань і $є$ автономним і мобільним санітарним пристроєм для дезінфекції закритих приміщень до $500 \mathrm{~m}^{3}$. Розроблено мікропроцесорний контролер для управління роботою озонатора. Представлено результати інактивації бактерій в двох різних приміщеннях для хірургічних операцій. 